STATE OF ILLINOIS

DEPARTMENT OF REGISTRATION AND EDUCATION

DIVISION OF THE

NATURAL HISTORY SURVEY

STEPHEN A. FORBES, Chief

\begin{tabular}{lll}
\hline Vol. XIV. & BULLETIN & Article II. \\
\hline
\end{tabular}

\title{
DISTRIBUTION OF THE FRESH-WATER SPONGES OF NORTH AMERICA
}

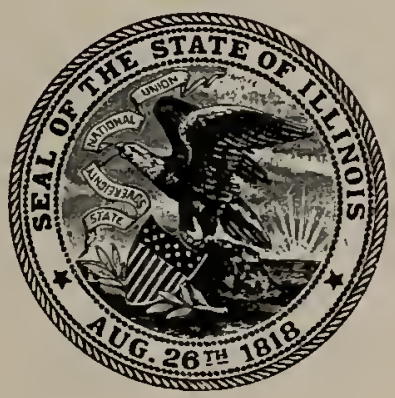

PRINTED BY AUTHORITY OF THE STATE OF ILLINOIS

URBANA, ILLINOIS

June, I92I 


\section{STATE OF ILLINOIS \\ DEPARTIENT OF REGISTRATION AND EDUCATION}

W. H. H. Mlller, Director

\section{BOARD OF \\ NATURAL RESOURCES AND CONSERVATION}

W. H. H. MILLER, Chairman

William Trelease, Biology John M. Coulter, Forestry Rollin D. Salisbury, Geology Wildial A. NoYes, Chemistry
JoHN W. ALvoRD, Engineering KenDRIC C. Bascock, Representing the Presilcnt of the University of Illinois

THE NATURAL HISTORY SURVEY DIVISION

Stephen A. Forbes, Chicf

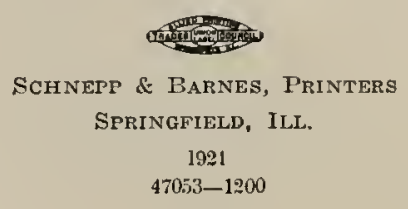


Article II.-On the Distribution of the Fresh-Water Sponges of North Amcrica.* By Frank Smith.

In the preparation of this paper there have been two purposes in mind. One of these is the presentation of the results of studies thus far made on the fresh-ivaler sponges of Illinois; and the other is to assemble in more convenient form the information which we now have concerning the distribution of such sponges in North America. Preliminary to the more detailed presentation of data it is desirable to give a brief summary of our knowledge of the fresh-water sponges of this continent.

\section{Historical}

The greater part of what is known on the subject at the present timc is the result of the work of less than a half dozen men, and was gained during the decade $1880-1890$. The most important work is that of Dr. Edward Potts, of Philadelphia, who contributed something over twenty short papers on the subject, besides his monograph-which appeared in 188\%. Most of his papers appeared in the Proceedings of the Philadelphia Academy of Sciences. His collecting was done chiefly in Pennsylvania and New Jersey, in the vicinity of Philadelphia. An active co-worker with Potts was Henry Mills, of Buffalo, N. Y., who collected in his own state and occasionally in Florida, Iowa, and northern Illinois. About a dozen brief papers and a few new species appear to his credit. His publications were chiefly in various journals of microscopy which abounded in the decade just mentioned. A. H. McKay, principal of an acadenty in Halifax, N. S., was an active collector in Nova Scotia and Newfoundland, and contributed a half dozen papers and a few species of uncertain status. B. W. Thomas, of Chicago, a devotee to microscopy, did a good deal of collecting in northern Illinois for other workers, but not much writing. This quartet of workers was in close relation with H. J. Carter, of England, who was one of the leading specialists in the whole group of sponges, and they with certain Canadian collectors supplied Carter with material which served as a basis for a few papers on American forms and for one new species.

Of the approximately thirty known species of North American freshwater sponges, about twenty were described during this decadc, chicfly by Potts, and but one of them by a European. Some ten or eleven specics were found in each of the states of Pennsylvania. New Jersey, and New

\footnotetext{
- Contributions from the Zoological Laboratory of the University of Illinois No. 174.
} 
York, and a similar number in Nova Scotia and Newfoundland; also eight each in Florida and Illinois. In the following decade, (1890-1900) Ohio was given a list of ten species, chiefly through the work of $D$. S. Kellicott, who published two small papers on the subject of fresh-water sponges. In 1916 the writer published a list of nine species for Michigan, this being the number found in connection with his work at the University of Michigan Biological Station at Douglas Lake, in the northern part of the state. In 1918 he also published the description of a new species from Oneida Lake, in the state of New York. A study of Illinois material collected by various investigators has brought the list for the state up to twelve species, which is the maximum number for any state, as far as is known to the writer. Almost nothing is known of the sponge fama of any state west of the Mississippi River and, with the exception of Florida, almost nothing of the sponge fauna of the southern half of the United States. Mills listed four species in Iowa, and the writer has found four species in the high-altitude lakes near Tolland, Colorado, in the vicinity of the University of Colorado Mountain Laboratory. As far as is known to him, not more than three species are recorded from any other state west of the Mississippi River. He will welcome information concerning more extended lists, if there be such. There is some evidence that the sponge fauna of the southern states will be found to differ in some respects from that of the northern ones. During the past fourteen years, N. Annandale, of the Indian Museum in Calcutta, has published numerous and important papers on fresh-water sponges, chiefly those of Asiatic regions; a few of them, however, have dealt with North American species. He has created one new genus, Asteromeyenia, for two of such species, and announced a few new locality records for others. His work was based on rather scanty collections belonging to the United States National Museum.

Four North American species were first found and described in Europe; while seven species first described in North America were subsequently found in Europe, and at least three of them also in Asia. About one third of our species are thus more or less widely distributed in the Northern Hemisphere.

\section{Systematic}

Important characters for the recognition of species are found in the spicules of the skeleton; in other spicules which may or may not be present in the sponge mass and are variously designated as flesh spicules, dermal spicules, or sarcode spicules; and in still others, known as genmunle spicules, which are intimately related to the gemmules. The gemmules are small seed-like bodies appearing in summer or autumn, and are involved in one important method of reproduction. In a few species the apertures of the chitinous walls of the gemmules are at the summit of tubular prolongations, and these in turn are sometimes provided with one or more filaments, borne at or near the margins of the apertures. For the positive identification of nearly all of our species, the presence of gemmules is necessary. 
The most serious defects in the work of Potts and his co-workers and of more recent workers who have depended on his monograph, have been due to the failure to recognize Ephydatia fluviatilis and E. milleri as distinct species. These are two very abundant and widely distributed forms and are also highly variable. Specimens of either species were indiscriminately designated Mcyenia fluviatilis, and nearly a dozen supposed species and varieties were named and described from various forms of one or the other of the two, and later all made synonyms of $M$. fluviatilis, now Ephy'datia fluviatilis. In some cases illustrations or descriptive statements indicate clearly enough which of the two species is involved, but often one can not tell. E. fuviatilis has birotulate gemnule-spicules with shafts longer than the diameter of the rotules, and the skeleton spicules uniformly smooth; while E. mülleri has the shafts usually shorter than the diameter of the rotules, and the skeleton spicules varying from distinctly spined or sparsely micro-spined to nearly or quite smooth. Distinctly spined and smooth spicules are often associated in the same specimen and in different ratios in different specimens. The gemmule walls of $E$. milllcri not infrequently include two or even three layers of birotulate spicules, while those of E. fuviatilis uniformly have but a single layer. Potts erroneously assumed that the distinction between these two species was based merely on the last-mentioned difference, and since the appearance of more than a single layer in the former species is not a constant character, he decided against the validity of the species.

Another source of error involving North American species, which is of less consequence because less confusing, has arisen from the description by Hilgendorf in 1882 of a Japanese sponge as variety japonica of $E$. Aluviatilis. Judging from the description, this is nothing other than the form of E. miilleri in wlich the skeleton spicules are smooth. Among the United States National Museum specimens examined by Annandale was one from the Potomac River which he listed in 1910 as E. japonica. recognizing this form as a distinct species. In 1916 after a study of Japanese sponges annong which were the various forms of E. millleri, he treated the japonica form as a variety of E. millleri. The writer believes that there is not sufficient basis for giving it even the rank of a variety. It is simply a very common variant form of a highly variable species. In the original description of E. milllcri the skeleton spicules were described as spined, but by various students of the species in England, Germany, and Austria the extremely variable condition has been well known and frequently mentioned. The specimens of this species in the writer's collections from different parts of Michigan, from high mountain-lakes of Colorado, and from Montana, indicate that those with smooth or nearly smooth skeleton-spicules and those with spined spicules are similarly distributed; and also that the same body of water may contain both of these kinds of specimens, and still others with spined and smooth spicules associated in the same skeleton fascicles. Among the Colorado specimens, those with spined skeleton-spicules are more frequent 
than those with smooth ones, but the distribution is similar; while in the Michigan material. specimens with smooth or nearly smooth skeletonspicules are most frequent. E. fluviatilis has a distribution similar to that of E. millleri, but is less abundant.

\section{ILLINOIS SPECIES}

In 1883 Henry Mills, of Buffalo. New York, found in the Calumet River, near Chicago, a sponge which he afterwards described under the name Plciomeycuia calumeticus, but which evidently was the form of Ephydatia milleri having smooth skeleton-spicules. In the same paper (18S4a) he mentions finding Carterius tubisperma in Illinois.

Mills read before the State Microscopical Society of Illinois, on May $2 \%, 188 \%$, a paper on fresh-water sponges which recorded eight species found in the state, and which was published in full in an issue of a local newspaper. Since it contains the earliest definite record of the occurrence in the state of some of the species mentioned, that part of the paper which describes the localities and gives the details of the collecting activities is here reproduced with a few typographic errors corrected. It appeared under the general heading. "Fresh Water Sponges", and with the following subheadings: "Paper by Henry Mills, of Buffalo, read before the Microscopical Society"; "Earliest Mention of this Species of Infusoria and Difficulty of their Classification"; "Record of a Scientific Party which lately Explored some of the Illinois Lakes".

On the 20th of September, 1886, a party consisting of B. W. Thomas and W. H. Summers, members of the State Nicroscopical Society, Chicago, and the writer made an effort to explore some of the lakes in Illinois, north of Chicago, with sanguine expectation of being able to add something to our list of genera and species of these and other microscopic objects; for, although the two Chicago gentlemen searched principally for Diatomaceous material, the writer gratefully acknowledges valuable help from them in the search for the objects of his special pursuit. We left Chicago by the afternool train on the Chicago and Northwestern Railway, arriving at McHenry, McHenry County, in time to prepare for an early start up the Fox River in the morning. Each of the party had his boat, and collecting apparatus, and those who felt like using the oars did so, while those who felt so inclined secured others to do the hard work. It was a cloudy and rather cool morn. ing, and by the time we reached "Dutchman's Slough," which is the outlet of a small sluggish stream or creek three and one-half miles north of McHenry, there was a drizzling rain, which threatened to dampen the enthusiasm of the party; but as it did not last long, we were soon ready for work. Although not immediately successful, there was enough enchantment in the spot and its surroundings to inspire us with confidence, and in a short time we reached a place in the slough where the sponge could he hauled hy the drags, with the weeds to which it was attached in large handfuls. The weeds or algae upon which the sponge grew consisted of a species of Utricularia, and Ana. charis canadensis (both of microscopic interest), and some others not recorded. Unfortunately the sponge, on examination at home with the microscope, proved to be mostly immature, containing but few statoblasts, but enough to determine the species as mostly Carterius tubisperma Mills; Meyenia fuviatilis and Meyenia Calumetica Thomas. But in the interest of science the spot should he remembered, that future investigators may be benefited at least to the extent of our discoveries in this interesting locality. Other micro- 
scopical material, especially Diatomaceae, was present in great abundance. The sponge was beautifully clean, of a bright, buff color, a small piece or perhaps a senarate sponge the size of a small hickory nut being attached to every frond of the Utricularia. After obtaining as much of this as we could care for, besides other material, we started up the river, passing through lakes Pistakee and Nippersink into Fox Lake, resting for the night at "Hotel Sayles," situate on Hickory Point, the dividing ridge between Lake Nippersink and Fox Lake. The following morning we found only some Diatomaceous material, and soon pushed off in the direction of Cedar Lake, which is about four miles from our hotel and two miles from Fox Lake. Here the wind, from an approaching storm, so ruffed tbe water as to make all attempts at collecting futile. On our return to the neighborhood of the hotel we succeeded in finding a large quantity of spongilla lacustris, which well repaid us for the disappointment in the earlier part of the day.

This sponge, unlike the former, was of a bright emerald green, growing in long digitate processes and branches, attached to weeds or stones in about three feet of water. Nothing could exceed the beauty of this sponge seen growing in the sunshine when the water was quite still. The vital action of the sponge could be seen, causing the gentle waving motion which is described as occurring in marine sponges. Had we made this gathering six weeks later in the season it would have been a real treasure, the statoblasts, which are now few, would by that time have been present in great abundance. The same party has made several excursions to the streams and sloughs south of Chicago. In the Calumet River, at Blue Island, fragments of sponges and some rare algae were found. The sponges consisted of Meyenia fluviatilis and spongilla lacustris, while the algae most noticeable were fine specimens of Chara and Nitella. These, for want of large jars, could not be preserved. In 1883 and in 1886 we visited the Cummins Bridge, over the Calumet River near Calumet Lake, and on both occasions were well rewarded with rich gatherings of sponges, Diatomaceae and other microscopic objects. Among these was a quantity of the Polyzoan Idae, the winter eggs of which are similar in physio. logical history to the statoblasts of the fresh-water sponge. Among the sponges found was Mreycnia fluviatilis. one peculiar variety of which was described and named some five years ago by Mr. B. W. Thomas as Meyenia calumetica; a small piece of Heteromeyenia argyrosperma. Potts; Carterius tubisperma. Mills; Carterius latitenta. Potts, and a variety of Heteromeyenia repens. Potts; also a variety of spongilla fragilis, Leidy, including one known as Spongilla fragilis variety Calumeti.

These statements are made with the hope that they will encourage otbers of like tastes and inclinations to make further search in this neglected, but interesting branch of study.

I know of no more promising field of research for the naturalist, whether for sponges. diatoms or other microscopical material, than the chain of small lakes and swamps in MlcHenry County, and the region extending from ten to thirty miles south and southwest of Chicago.

It is practically certain that some of the specimens which were identified in the above report as Meyenia fuviatilis or one of its varieties, were actually Ephydatia milleri, but there is considerable probability that $E$. furiatilis was also represented.

Asteromeyenia radiospiculata is reported from Granite City, Illinois, by Annandale in a brief paper (1911) in which he created the genus Asteromeyenia to receive two North American species which have radiate dermal spicules, and gemmule spicules of two or more distinct classes.

Sponges collected by R. E. Richardson, and others, in the Illinois River at various locations, in connection with certain investigations of the 
I1linois State Laboratory of Natural History in 1912-1914, have been identified by the writer as follows, the locality records being added: Spongilla fragilis was generally distributed from Starved Rock, near La Salle, to Meredosia at least; Ephydatia fuzriatilis was found in sloughs near Havana; Carterius latitenta was abundant from Starved Rock to Copperas Creek; Astcromeycnia radiospiculata was found at Hardin and Grafton; Trochospongilla leidyi was abundant from La Salle to Hardin; and one specimen of $T$. horrida was found at Starved Rock. A second specimen of the last-named species was collected by A. A. Hinkley in the southern part of the state in the Big Muddy River near Waltonville in 1914. As far as is known to the writer the above are the first records for $T$. horrida in North America.

Ephydatia crateriformis and Spongilla fragilis have been collected in the Sangamon River, at places a few miles west of Urbana, but the stream is too muddy to permit the development of an extensive sponge fauna. Collections from ponds and streams of the drainage basin of Salt Fork, a branch of the Vermilion River, at various places from Urbana to Muncie (which is about twenty miles farther east), have contained Spongilla fragilis, Ephydatia fluviatilis, E. crateriformis, and Carterius latitenta. The first- and last-named species are the most abundant. The total of twelve species already recorded should be increased somewhat when careful collecting has been done in other parts of the state.

\section{Additional North American Records}

Collections received from various sources have made it possible to list species from a few states from which sponges had not been previously reported, and to add species to the lists previously reported from several other states. Reference to some of these new records has been made in the key to sponges contained in Ward and Whipple's Fresh-Water Biology. The new records are indicated in the distribution table (page 1\%) by the letter $\mathrm{S}$. The United States National Museum has several specimens which add previously unrecorded species to the lists of each of seven states, and these are indicated in the table by the letter $U$. A brief summary of the new records and the data of the collections on which they are based follows. The order of sequence in presenting the items is determined by their geographic distribution from east to west, and from north to south.

Spongilla lacustris in a collection made by A. O. Gross in the vicinity of Brunswick, Maine.

Spongilla igloviformis and Tubclla pennsylvanica in a collection made by Miss Elizabeth Bodfish from a pond near Palmer, Massachusetts.

Ephydatia crateriformis in a collection of the United States National Museum, from the Potomac River at Washington, D. C., and Spongilla lacustris from Pomonkey Creek, Maryland. 
Heteromeyenia ryderi in a collection of the above-named museum, from the Disnal Swamp in Virginia; and Ephydatia milleri, from Dyke, Virginia.

Eplydatia cratcriformis in a collection of the same museum, from the moutl of the Shiawassee River in Michigan.

Heteromeyenia repens in a collection of the same museum, from the outlet of Lost Lake, in Indiana.

Trochospongilla leidyi in a collection of the same museum, from Frankfort, Kentucky.

Tubella pennsylvanica in a collection made by A. T. Evans, near Rhinelander, Wisconsin; and Carterius latitenta, one gemmule, in débris from the bottom of Lake Mendota. Wisconsin.

Spongilla fragilis in a collection from N. M. Grier, made in Lake Pepin, Minnesota; and S. lacustris in a collection made by H. V. Heimburger near St. Paul, Minnesota.

Spongilla fragilis in a collection from the United States Fisheries Station at Fairport, Iowa.

Spongilla fragilis and $S$. lacustris in a collection made by Dr. Mary T. Harman near Manhattan, Kansas; and Cartcrius tubisperma in a collection of the United States National Museum, from Goodland, Sherman county, Kansas.

Spongilla lacustris and Ephydatia milleri (typical form with spined skeleton-spicules) in a collection made by Miss Bessie R. Green from a pond near Flathead Lake in Montana.

Spongilla fragilis and $S$. lacustris in a collection made by Professor S. A. Forbes in the year 1890 in Yellowstone Park, Wyoming.

Spongilla fragilis, S. lacustris, Ephydatia furiatilis, and E. milleri in collections by the writer in the vicinity of Tolland, Colorado, in the year 1916. Sponges were found in eleven of the thirty ponds and lakes examined and are probably contained in others. Apparent absence was probably due in some instances to the very brief time allowed for making collections. Ephydatia fuviatilis was found only in Smartweed Lake, which has an altitude of about 8,575 feet. Spongilla fragilis was found in ten bodies of water with altitudes ranging from 8,100 to 10,580 feet. $S$. lacustris was collected in seven ponds and lakes, with altitudes of 8,850 to 10.580 feet, and Ephydatia mulleri in four of the same. Lower Crater Lake (alt. 10,580 ft.), yielding the three species last named, was the highest of the bodies of water in which sponges were found during the summer of 1916. In August, 1913, Spongilla lacustris was collected in the same vicinity, in West Forest Lake, which has an altitude of about 10,800 feet.

Spongilla lacustris in a collection made by H. L. Osterud in Lake Washington, near Seattle, Washington.

Carterius tubisperma in a collection of the United States National Museum, from Fresno. California. 
Spongilla lacustris has recently been received from Dr. F. Johansen, who collected it during the summer of 1920 in a pond on an island in James Bay, Canada, latitude about $521 / 2^{\circ} \mathrm{N}$.

Specimens without gemmules, which are probably Spongilla lacustris, were collected by Professor H. B. Ward in July, 1919, in Long Lake, in the Copper River Basin, Alaska, latitude $61^{\circ} 25^{\prime} \mathrm{N}$.

Major George H. Conklin, M. D., of Superior, Wisconsin, who was an enthusiastic collector and student of fresh-water sponges about thirty years ago, has furnished the following list of species found by him during the years 1890,1891 , and 1892 at various places in Douglas county, in the northwestern part of IVisconsin: Spongilla fragilis, S. lacustris, S. igloviformis, Ephydatia fuviatilis, E. crateriformis, Hetcromeycnia argyrosperma, Tubclla pennsylaranica, and Carterius tubispermo. Unfortunately his collections were destroyed by fire some years ago. It is probable that the name Ephydatia fluziatilis was applied to both E. Aluriatilis and E. mullleri in accordance with the practice of Potts and other American workers of the time. The only record differing from what one would expect, considering the records in neighboring states, is that of Spongilla igloviformis, this being the only report of it west of the Alleghany Mountains.

\section{Tabular Presentation of Distribution Data}

Records of the North American species of fresh-water sponges and the states from which they have been reported in various scientific publications are indicated in the following table by an asterisk. As stated on preceding pages, new records in this paper are indicated by the letter $S$; records from the paper by Mills, quoted on preceding pages and not otherwise listed, are indicated by the letter $M$; unpublished records based on specimens in the United States National Museum are indicated by the letter $\mathrm{U}$; and records of species in Wisconsin, furnished by Dr. Conklin, and not otherwise listed, are indicated by the letter C. In a few cases in which Ephydatia furriatilis is reported, there is nothing to indicate that the specimens may not actually have been $E$. millleri, the record is therefore indicated by an interrogation point under each name.

It is not inprobable that a few published records have been omitted from the table, since several papers dealing with the subject have not been accessible, but this is intended to serve only as a "report of progress." 


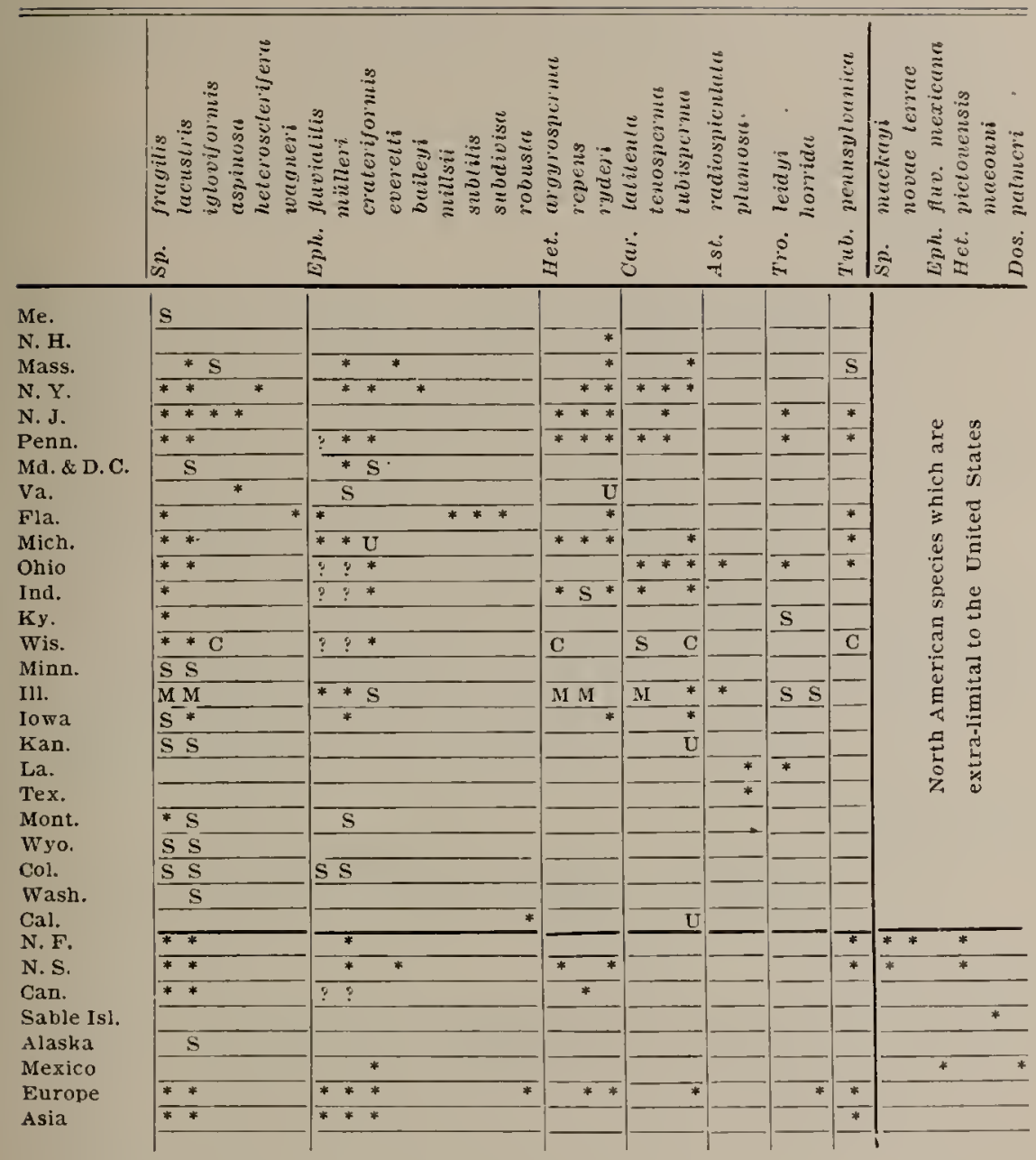




\section{LITERATURE DEALING WITH FRESH-WATER SPONGES OF NORTH AMERICA}

Adans, C. C.

1909. An ecological survey of Isle Royale, Lake Superior. Rep.

Mich. Geol. Surv., 1908. (Sponges, p. 249-250.)

Annandale, $\mathrm{N}$.

1909. Fresh-water sponges in the collection of the United States National Museum.-Part II. Specimens from North and South America. Proc. U. S. Nat. Mus., 3\% : 401-406.

1910. Fresh-water sponges in the collection of the United States National Museum.-Part IV. Note on the fresh-water sponge, Ephydatia japonica, and its allies. Iden, 38 : 649-. 650.

1911. Fresh-water spnoges in the collection of the United States National Museum.--Part V. A new genus proposed, with Heteromeyenia radiospiculata Mills as type. Idem, 40: $593-594$.

Baker, F. C.

1918. The productivity of invertebrate fish food on the botton of Oneida Lake, with special reference to mollusks. Tech. Pub. No. 9, N. Y. State Coll. For. (Sponges, p. 186-18\%.) Syracuse.

Bowerbank, J. S. .

1863. A monograph of the Spongillidae. Proc. Zool. Soc. Lon: don, 1863 , p. 440-472.

1864. Description of two Anlerican sponges. Can. Nat. and Geol. (n. s.) $1: 304-30 \%$.

Carter, H. J.

1881. On Spongiophaga in Spongilla. Ann. Mag. Nat. Hist. (5) $8: 222$.

1881a. On Spongiophaga pottsi. Ann. Mag. Nat. Hist. (5) 8 : $354-$ 362.

1882. Form and nature of the cirrous appendages on the statoblast of Carterclla latitenta Potts, etc., originally designated Spongiophaga pottsi. Ann. Mag. Nat. Hist. (5) $9: 390-$ 396.

1885. Note on Spongilla fragilis, Leidy, and a new species of Spongilla (Mackayi) from Nova Scotia. Ann. Mag. Nat. Hist. (5) $15: 18-20$.

18s5a. On a variety of the fresh-water sponge, Meyenia Aluviatilis. Ainn. Mag. Nat. Hist. (5) $15: 453-456$.

$1885 \mathrm{~b}$. On a variety of the fresh-water sponge, Meyenia furviatilis, from Florida. Ann. Mag. Nat. Hist. (5) $16: 179-181$. 
Clark, H. James

1871. The American Spongilla, a craspedote, flagellate infusorian. Am. Jour. Sci. and Arts. (3) $2: 426-436$.

Dawson, G. M.

1878. On some Canadian species of Spongilla. Can. Nat. (n. s.) $8: 1-5$.

Edwards, Arthur M.

1896. Sponges considered microscopically. Am. Month. Micr. Jour. $16: 379-381$.

Evermann, B. W., and Clark, H. W.

1920. Lake Maxinkuckee-a physical and biological survey. 2 vol. Pub. by Dept. Conserv. Indiana. (Sponges, 2 : 103104.)

Forbes, S. A.

1893. A preliminary report on the aquatic invertebrate fauna of the Yellowstone National Park, Wyoming, and of the Flathead Lake region of Montana. Bul. U. S. Fish Comm. $11: 207-258$.

Hankinson, T. L.

1916. Observations on the Fishes of Houghton county, Michigan. Pub. 20, Biol. Ser. 4, Mich. Geol. and Biol. Surv. (Sponges, p. 1\%.)

1916a. Results of the Shiras expeditions to Whitefish Point, Michigan: fishes. Idem. (Sponges, p. 118.)

Kellicott, D. S.

1891. The Mills collection of fresh-water sponges. Bul. Buffalo Soc. Nat. Sci. 5 : 99-10t.

1897. Preliminary report on the fresh-water sponges of Ohio. 5th Ann. Rep. Ohio State Acad. Sci., p. 50.

Kirsch, A. M.

1909. Fresli-water sponges and particularly those of the United States. Midland Naturalist, Notre Dame, Ind., 1 : 29-38. 1909a. Carterius both a synonyme and homonyme. Idem, 1:60.

Kofoid, C. A.

1899. The plankton of Echo River, Mammoth Cave. Trans. Am. Micr. Soc. 21 : 113-126.

1908. Plankton studies. V. The plankton of the Illinois River, 1894-1899. Part II. Constituent organisms and their seasonal distribution. Bul. Ill. State Lab. Nat. Hist. 8 : 1-361. (Porifera on p. 132.) 
Landacre. F. L.

1902. Sponges and bryozoans of Sandusky Bay. Ohio Nat. 1 : $96-9 i$.

Leidy, Joseph

18.j1. Spongilla fragilis. Proc. Acad. Nat. Sci. Phil. 5 : 2:s.

Lockwood, S.

1.88\%. Heteroneyenia ryderi. Jour. X. Y. Micr. Soc. 1 : $3 i-10$.

Mackay, A. H.

180\%. Notes on Jova Scotia iresh-water sponges. Proc. Trans. Nova Scotia Inst. Nat. Sci. $6: 145-14$ S.

188ja. Notes on the iresh-water sponges of Nova Scotia. Idem, $6: 233-240$.

130.jb. Organic siliceous renains in the lake deposits of Nova Scotia. Can. Rec. Sci. 1 : 2:36-24t.

1086. New iresh-water sponges from Nova Scotia and Newfoundland. Idem. : : 11-??.

150:. The iresh-water sponges of Newioundland. Idem, 2 : 19i499 .

1ss9. Fresh-water sponges of Canada and Newfoundland. Trans. Roy. Soc. Can. : :

1900. A fresh-water sponge irom Sable Island. Proc. Trans. Nova Scotia Inst. Nat. Sci. $10: 319-32 ?$.

Mills, $\mathrm{H}$.

18.0. Fresh-water sponges. Am. Tour. Micr. and Pop. Sci. 5: $125-132$.

1s51. New fresh-water sponges. Idem, 6 : 30-31.

185?. Votes on the Spongillae of Buffalo. Bul. Buffalo Soc. Nat. Sci. 1 : $5 i-60$.

1882a. Fresh-water sponge. Proc. Am. Soc. Micr. 1882, p. 209-216.

188t. Serial arrangement of birotulate spicules in statoblasts of American sponges. Am. Monthly Micr. Jour. j : $11-12$.

$158+a$. Thoughts on the Spongidae, with reference to the American sponges of the iresh-water group. with some account of them in detail. Proc. Am. Soc. Micr.. 1884. p. 131-14\%.

158:. Notes on the genus Carterius, formerly Carterella, of the fresh-water sponges. Microscope, $;:$ : 161-164.

188ia. Hints on the iresh-water sponges. Idem i : 291-29i.

1888. A new Iresh-water sponge. Heteromeyenia radiospiculata n. sp. Idem. \& : 5:-53.

1889. Fresh-water sponges. Jour. Micr. and Nat. Sci. (n. s.) 2 : 82-85. 
Muttkowski, R. A.

1918. The Fauna of Lake Mendota-A qualitative and quantitative survey with special reference to the insects. Trans. Wis. Acad. Sci. Arts, Let. 19:374-18\%. (Porifera on P. 388.)

Needham, J. G.

1908. Report Entomologic Field Station conducted at Old Forge, N. Y., in the summer of $190 \%$. N. Y. State Mus. Bul. No. 12t. (Sponge report, p. 163.)

Potts, Edward

1880. Fresh-water sponges of Fairmount Park. Proc. Acad. Nat. Sci. Phil. 1880 , p. 330-331.

1881. On fresh-water sponges. Idem, 1880, p. 35\%-35\%.

18s1a. Some new genera of fresh-water sponges. Idem, 1881, p. 149-150.

1881b. A new form of fresh-water sponge. Idem, 1881, p. 1 ir6.

1882. The genus Carterella vs. Spongiophaga Pottsi. Idem, 1881, p. $460-163$.

1S82a. Three more fresh-water sponges. Idem, 18s2, p. 12-14.

18s?b. Sponges from the neighborhood of Boston. Idem, 18s2, p. $69-20$.

1883. Fresh-water sponges. what, where, when, and who wants them. Bul. L. S. Fish Comm. 3 : 389-391.

1883a. Our fresh-water sponges. Am. Nat. 12 : 1293-1296.

185t. Fresh-water sponges as improbable causes of the pollution of river-water. Proc. Acad. Nat. Sci. Phil. 18\$4, p. 28-30.

18sta. Some modifications observed in the form of sponge spicules. Idem, 1884. p. 18t-185.

$1854 \mathrm{~b}$. On the wide distribution of some American sponges. Idem, 1884. p. 215-21\%.

1s8tc. On the minute fauna of Fairmount Reservoir. Idem, 1Sst, p. 21 i-219.

1885. A new fresh-water sponge from Nova Scotia. Idem, 1885. p. 2S-29.

1885a. A fresh water sponge from Mexico. Am. Nat. 19: 810-\$11.

18s5b. Fresh-water sponges from Mexico. Proc. U. S. Nat. Mus. $8: 58 i-589$.

1Ss6. Fresh-water sponges from Newfoundland: A new species. Proc. Acad. Nat. Sci. Phil. 1886, p. ?2:-230.

1S5\%. Fresh-water sponges. A monograph. Idem, 188\%, p. i-iv and 15i-2i9 (Reprint.)

1889. Report upon some tresh-water sponges collected in Florida by Jos. Willcox, Esq. Trans. Wagner Inst. Phil.? : 5-? 
1890. Fresh-water sponges. I. What they are not. Microscope, $10: 140-143$. II. What they are. Idem, 10:161-163. III. What they are. The spicules. Idem, 10:193-196. IV. How to find and gather then. Idem, 10:25\%-263. $\mathrm{V}$. The determination of species. Idem, $10: 30 \%-310$.

1918. The sponges (Porifera). Chapter $\mathrm{X}$ in Ward and Whipple's Fresh-Water Biology. New York.

Priest, B. W.

1884. Statoblasts of the fresh-water sponges. Am. Monthly Micr. Jour. 4 : 208-213.

Shelford, V. E.

1913. Animal communities in temperate America as illustrated in the Chicago region. (Sponges, p. 153.) Univ. Chicago Press, Chicago.

Snith, F.

1918. A new species of Spongilla from Oneida Lake, New York. App., Tech. Pub. No. 9, N. Y. State Coll. For. p. 239-242.

Snith, F., and Green, Bessie R.

1916. The Porifera, Oligochaeta, and certain other invertebrates in the vicinity of Douglas Lake, Michigan. Rep. Mich. Acad. Sci. 17 : 81-84.

Stedman, J. M.

1891. The nervous system of the fresh-water sponge. Proc. Am. Soc. Micr. 13 : $77-78$.

Waller, J. G.

189\%. The president's address. Jour. Quek. Micr. Club. $6: 333-344$.

Ward, H. B., and Whipple, G. C.

1918. Fresh-water biology. (Sponges, p. 301-315.) New York.

Washburn, F. L.

1898. A preservative for fresh-water sponge. Jour. Applied Micr. $1: 73$.

Weltner, W.

1895. Spongillidenstudien. III. Katalog und Verbreitung der bekannten Süsswasserschwämme. Arch. f. Naturg. 61 : 114144. 